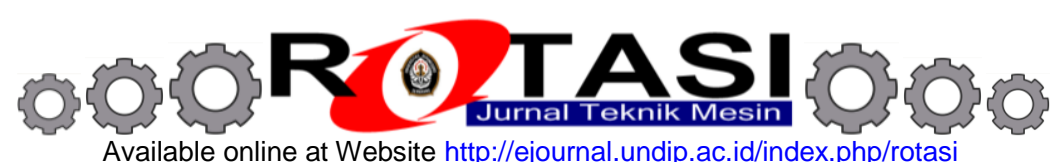

Available online at Website http://ejournal.undip.ac.id/index.php/rotasi

\title{
STUDI LITERATUR PENGARUH PARAMETER PENGELASAN TERHADAP SIFAT FISIK DAN MEKANIK PADA LAS TITIK (RESISTANCE SPOT WELDING)
}

\author{
*Haikal ${ }^{1}$, Triyono ${ }^{2}$ \\ Mahasiswa Jurusan Teknik Mesin, Fakultas Teknik, Universitas Sebelas Maret \\ Dosen Jurusan Teknik Mesin, Fakultas Teknik, Universitas Sebelas Maret \\ Jl. Ir. Sutami 36 A Kentingan Surakarta 57126 \\ *E-mail: haikal_kalkal@yahoo.co.id
}

\begin{abstract}
Resistance spot welding (RSW) is the most widely used for joining thin sheet metals in automotive industry. Various applications of dissimilar materials and thicknesses were commonly found in many spot welding processes especially in the manufacture of car body. The resistance spot welding of dissimilar materials are generally more challenge than similar materials due to differences in the physical, chemical, and mechanical properties of the base metals. Differences of materials have an impact on heat input generated at the spot welding. Diameter of the weld nugget size is influenced by several parameters such as electric current, welding time, different types of material, and the thickness of the plate. Nugget diameter will influence on physical and mechanical properties weld such as microstructure, shear strength and hardness. For practical use, various industrial standards have recommended a minimum weld size for a given sheet thickness, mostly in the form of tables. For example the American Welding Society (AWS), Society of Automotive Engineering (SAE) and the American National Standards Institute (ANSI). They were only suitable to be apllied on the similar metal and thickness joint because in this joint, symetrical nugget will be formed. Meanwhile a type of dissimilar metal that joined by spot welding method will result in the asymetrical nugget. This paper aims to review the results of researchs on the similar and dissimilar resistance spot welded joint to evaluate the use of similar metals weld parameters and standards on the dissimilar metals weld. It was determined that parameters welding such as electric current, welding time, and the standard for similar metals weld can not be applied on the dissimilar metals weld. The asymetrical nugget shape decreased shear strength on the weld nugget. The most important factor that was considered on the dissimilar metals weld to make high quality weld joint was nugget diameter. If the nugget diameter weld increased the strength of welding will increase.
\end{abstract}

Keywords: resistance spot welding, welding joint, similar metals, dissimilar metals

\section{PENDAHULUAN}

Resistance spot welding (RSW) merupakan proses pengelasan yang banyak digunakan di industri otomotif seperti pembuatan bodi kendaraan. Selain itu, proses las titik ini juga banyak digunakan di industri elektronik, penerbangan, dan sektor nuklir. Pouranvari [1] mengatakan bahwa kendaraan modern mengandung 2000 sampai 5000 sambungan las titik. Proses RSW dipilih, karena sebagian besar bahan yang dipakai dalam proses perakitan bodi kendaraan adalah plat tipis, sehingga apabila menggunakan proses las yang biasa (SAW, SMAW, dan lain sebagainya), maka material tersebut akan mengalami penurunan sifat mekanik. Keuntungan lainnya adalah proses pengerjaannya membutuhkan waktu yang singkat dan permukaan yang akan dilas biasanya tidak perlu dibersihkan sebelum pengelasan. Pengelasan titik juga dapat dimodifikasi dengan menambahkan aplikasi robotik sehingga sangat efektif untuk industri yang menggunakan jalur produksi otomatis dan produksi secara massal. Metode las ini juga cocok untuk produksi kecil, karena fleksibel, peralatan proses sederhana, biaya relatif murah dan pengelasan mudah untuk dikontrol.

Kualitas dan kekuatan hasil sambungan las titik sangat penting dalam kelayakan dan keamanan alat transportasi sehingga perlu dilakukan penelitian lebih dalam. Penelitian tentang las titik telah banyak dilakukan oleh peneliti terdahulu yang bertujuan untuk mengetahui parameter yang dapat mempengaruhi hasil las. Parameter las titik sangat berpengaruh terhadap sifat fisik dan mekaniknya yang meliputi kemampuan menahan beban geser, kekerasan, dan perubahan strukturmikro. Parameter yang mempengaruhi hasil pengelasan titik berdasarkan hasil berbagai penelitian adalah kuat arus listrik, lama waktu pengelasan, jenis material, dan ketebalan plat.

Kegagalan pada las titik dibagi menjadi 2 tipe yaitu Interfacial failure (IF) dan Pull out failure (PF). Interfacial failure merupakan kegagalan dalam pengelasan titik dimana terjadi kerusakan atau keretakan pada zona fusi. Pull out failure merupakan kegagalan dimana terjadi kerusakan pada daerah sekitar zona fusi sehingga plat mengalami kerusakan yaitu plat sobek. Pull out failure merupakan tipe kegagalan yang diharapkan oleh engineer karena memiliki kemampuan menahan beban geser lebih besar dibandingkan Interfacial failure. Parameter terpenting dalam mencari tipe kegagalan RSW adalah ukuran nugget las. Industri telah merekomendasikan berbagai macam standar ukuran minimal nugget las untuk ketebalan plat tertentu agar memudahkan dalam pengelasan. Standar tersebut antara lain 
American Welding Society (AWS), Society of Automotive Engineering (SAE) dan American National Standards Institute (ANSI) telah merekomendasikan persamaan 1 untuk mencari ukuran las minimum.

$$
\mathrm{d}=4 \sqrt{t}
$$

dimana d dan $\mathrm{t}$ adalah ukuran nugget las dan ketebalan plat dalam satuan mm. Akan tetapi, rumus tersebut umumnya digunakan untuk menggabungkan logam baja sejenis dengan ketebalan sama.

Jenis material dan ketebalan plat merupakan parameter yang paling banyak diteliti oleh para ilmuwan. Hal ini dikarenakan dalam pembuatan struktur transportasi hampir seluruhnya menggabungkan 2 jenis material atau lebih dengan ketebalan yang berbeda. Pengelasan titik untuk menghubungkan 2 jenis atau lebih untuk material yang sama dengan material berbeda akan menghasilkan sifat fisik dan mekanik berbeda. Setiap material memiliki sifat yang berbeda yaitu kekuatan geser, konduktivitas listrik, konduktivitas termal, kekerasan. Konduktivitas listrik sangat berpengaruh dalam pengelasan titik. Panas las dihasilkan dari hambatan arus. Perbedaan nilai hambatan yang dimiliki oleh logam akan berdampak terhadap panas yang dihasilkan dari pengelasan titik. Panas tersebut akan membuat permukaan logam melebur satu sama lain sehingga 2 logam dapat tersambung. Logam sejenis apabila disambungkan dengan proses las titik akan menghasilkan panas yang sama pada sisi permukaan. Sedangkan untuk logam tak sejenis akan menghasilkan panas yang berbeda pada sisi permukaaanya. Untuk mengetahui apakah parameter pengelasan titik logam sejenis dapat digunakan pada pengelasan logam tak sejenis, dibutuhkan pengkajian lebih mendalam berdasarkan penelitian tentang las titik. Paper ini membandingkan sifat fisik dan mekanik sambungan las titik material sejenis dan sambungan las titik material tak sejenis.

\section{TINJAUAN PUSTAKA}

Pengaruh ketebalan plat merupakan salah satu faktor yang mempengaruhi hasil las titik. Penelitian terhadap ketebalan plat telah dilakukan oleh Pouranvari [1] yang melakukan penelitian tentang pengaruh kuat arus listrik pada las titik untuk baja dengan ketebalan berbeda terhadap kekuatan tarik. Penelitian ini bertujuan untuk mengetahui pengaruh dari ketebalan plat terhadap ukuran diameter nugget dan kekuatan tarik hasil las. Pengelasan ini menggunakan plat baja karbon rendah dengan ketebalan plat 1.25 digabungkan dengan plat ketebalan $2.5 \mathrm{~mm}$. Variasi kuat arus listrik dalam pengelasan antara 7 sampai $13.5 \mathrm{kA}$, sedangkan waktu pengelasan yaitu 0.2 dan $0.6 \mathrm{~s}$. Hasil penelitian menunjukkan bahwa perbedaan ketebalan plat menyebabkan terbentuknya nugget yang tidak simetris seperti terlihat pada Gambar 1 .
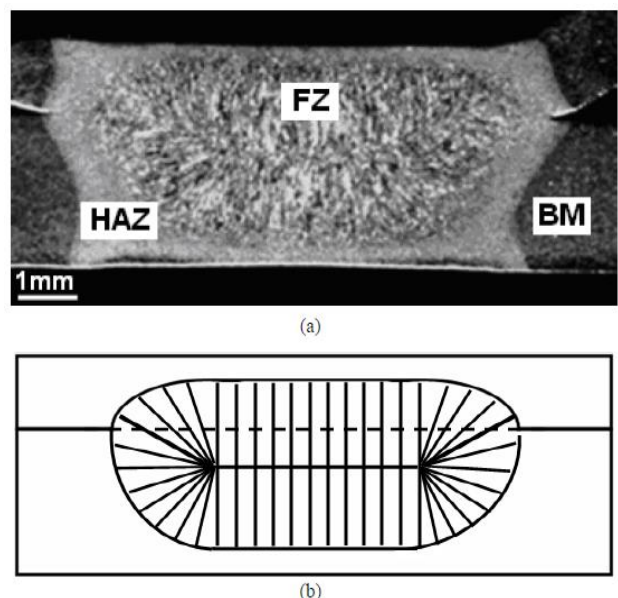

Gambar 1. Ketidaksimetrisan nugget hasil las [1].

Ketebalan plat juga berpengaruh terhadap penetrasi las titik. Penetrasi merupakan kedalaman logam mengalami peleburan. Penetrasi dari hasil las relatif terhadap kuat arus listrik pengelasan dapat dilihat pada gambar 2. Gambar tersebut menunjukkan semakin meningkat kuat arus listrik maka semakin meningkat pula persentasi penetrasi dari hasil las. Penetrasi diukur dari kedalaman penetrasi plat dibagi dengan ketebalan plat. Plat dengan ketebalan $2.5 \mathrm{~mm}$ memiliki nilai persentasi penetrasi lebih besar dibandingkan ketebalan $1.25 \mathrm{~mm}$. Bentuk nugget pada Gambar 1 . merupakan bentuk yang tidak simetris. Hal ini disebabkan tidak seimbangnya panas yang timbul antarmuka plat. Keseimbangan panas dapat didefinisikan sebagai kondisi dimana daerah zona fusi pada kedua plat memiliki kedalaman penetrasi nugget yang sama. Panas, konduktivitas elektrik material, serta geometri elektroda berpengaruh terhadap keseimbangan panas pada las titik. Untuk ketebalan plat berbeda, hambatan jenis total (bulk resistivity) yang dimiliki plat yang tebal jauh lebih besar dibandingkan dengan plat yang tipis. Hal ini membuat bentuk nugget dari hasil las titik tidak simetris. Uji geser dilakukan dengan menggunakan mesin UTM (Universal Testing Machine). Hasil penelitian di atas menunjukkan bahwa semakin besar kuat arus listrik pengelasan maka semakin meningkat beban puncak seperti 
ditunjukkan pada Gambar 3. Umumnya kegagalan pada las titik dibagi menjadi 2 tipe yaitu Interfacial failure (IF) dan Pull out failure (PF). Interfacial failure merupakan kegagalan dalam pengelasan titik dimana terjadi kerusakan atau keretakan pada zona fusi. Sedangkan Pull out failure merupakan kegagalan dimana terjadi kerusakan pada daerah sekitar zona fusi sehingga plat mengalami kerusakan yaitu plat sobek seperti pada Gambar 4. Pull out failure merupakan tipe kegagalan yang dibutuhkan dalam design of manufacture. Hal ini dikarenakan tipe Pull out failure memiliki deformasi plastik yang tinggi.

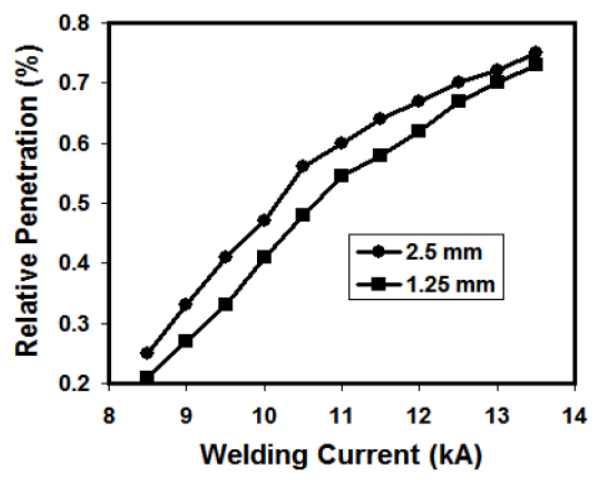

Gambar 2. Pengaruh kuat arus listrik terhadap kedalaman las [1].

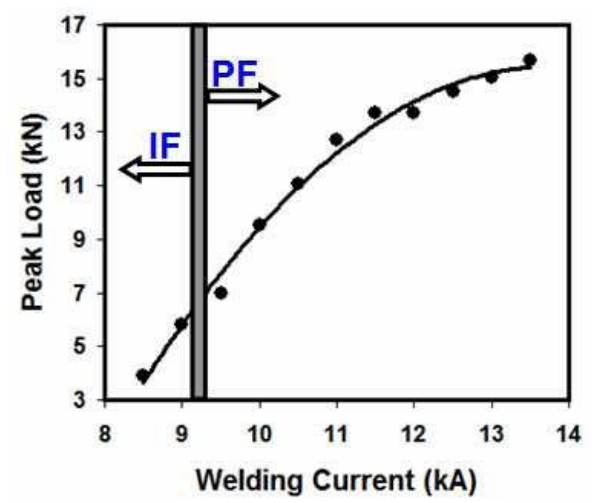

Gambar 3. Pengaruh kuat arus listrik pengelasan terhadap beban puncak [1].

Penelitian terhadap metode pengelasan titik tidak hanya dilakukan dengan percobaan tetapi juga dapat menggunakan software. Penelitian tentang pengelasan titik menggunakan software telah dilakukan oleh Ninshu dan Hidekazu [2] yang melakukan penelitian tentang pengaruh kuat arus listrik dan waktu pengelasan terhadap ukuran nugget pada proses las titik secara numerical dan experiment. Penelitian ini bertujuan membandingkan hasil analisa menggunakan software FEM (Finite Element Method) dengan hasil percobaan. Pengelasan menggunakan plat tipe baja karbon tinggi dengan ketebalan 0.7, 1.4, $1.8 \mathrm{~mm}$. Pengelasan dilakukan dengan susunan plat 3 lapis dan gaya penekanan elektroda konstan. Variasi arus listrik yang digunakan dalam pengelasan yaitu 5, 6, dan $7 \mathrm{kA}$, sedangkan variasi waktu yang digunakan yaitu 4, 5, 7, 10, 13, dan 17 detik. Dari hasil hasil penelitian menunjukkan bahwa nugget tidak terbentuk sebelum 4 detik dan ukuran nugget mulai meningkat setelah 5 detik. Berikut adalah data yang dihasilkan dari software FEM disajikan seperti terlihat pada Gambar 4. Gambar tersebut menunjukkan kuat arus listrik dan waktu pengelasan sangat berpengaruh terhadap ukuran nugget hasil las titik. Nugget hasil las akan berdampak pada sifat mekaniknya yaitu kekuatan geser.

Penelitian menggunakan software juga pernah dilakukan oleh Kong dkk [3] yang melakukan penelitian tentang numerical untuk kekuatan hasil las titik pada baja karbon rendah. Hasil penelitian menunjukkan bahwa meningkatnya diameter nugget untuk dua plat sejenis berdampak terhadap meningkatnya kekuatan geser sambungan las titik. Ketebalan plat juga berpengaruh terhadap meningkatnya kekuatan geser hasil las untuk plat dengan ketebalan yang sama seperti ditunjukkan pada Gambar 5. 


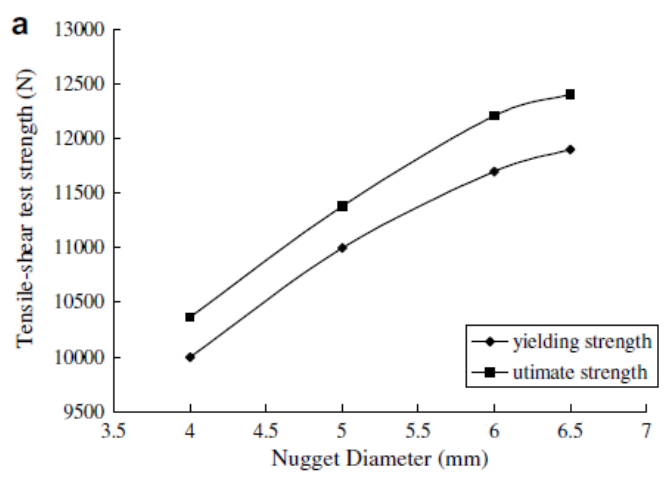

(a)

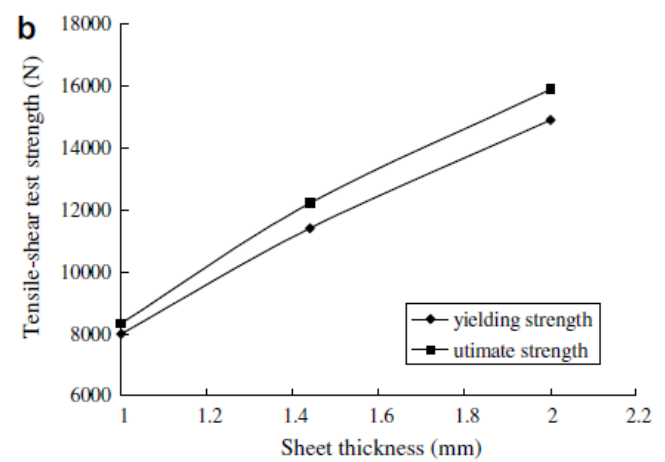

(b)

Gambar 5. Pengaruh diameter nugget dan ketebalan terhadap kekuatan tarik. (a) Pengaruh diameter nugget terhadap yeild dan ultimate strength (diameter nugget 4, 5, 6, $6.5 \mathrm{~mm}$ ); dihadapan (b) Pengaruh ketebalan plat terhadap yeild dan ultimate strength (ketebalan plat 1, 1.44, $2 \mathrm{~mm}$ ) [3].

Ketebalan plat dan jenis material berpengaruh terhadap momen bending dari hasil las titik. Penelitian terhadap ketebalan plat telah dilakukan oleh Dongho Bae [4] yang melakukan penelitian tentang pengaruh jenis material dan ketebalan plat terhadap momen bending. Material yang digunakan adalah stainless steel tipe SUS 301 L dengan ketebalan antara 1 - 4.5 mm. Software FEM (Finite Element Modeling) digunakan untuk mengetahui distribusi tegangan yang terjadi pada las titik dengan susunan plat 2, 3, 4 lapis seperti terlihat pada Gambar 6. Hasil penelitian menunjukkan bahwa konsentrasi tegangan dan deformasi meningkat seiring dengan meningkatnya celah antar plat.

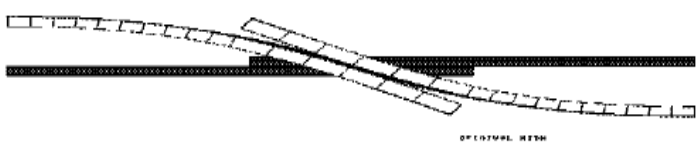

(a)

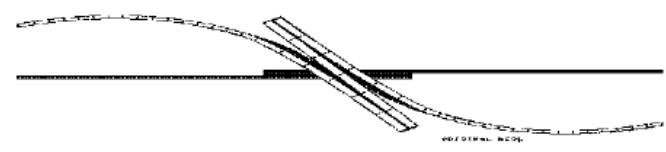

(b)

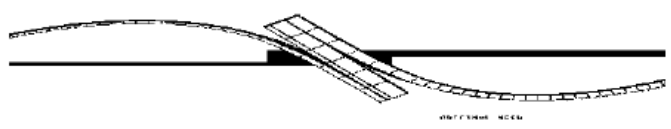

(c)

Gambar 6. Distribusi tegangan dan deformasi: (a) Susunan 2 plat; (b) Susunan 3 plat; (c) Susunan 4 plat [4]. 
Perbedaan jenis material pada pengelasan titik juga berdampak terhadap hasil las. Hal ini pernah diteliti Vural dkk [5] yang melakukan penelitian tentang pengaruh ukuran diameter nugget terhadap sifat fisik dan mekanik pada pengelasan titik untuk baja berbeda material. Penelitian ini menggunakan baja AISI 304 dan baja galvanis dengan variasi arus antara 5.5 sampai $13.5 \mathrm{kA}$. Pengelasan dilakukan dengan susunan plat yaitu AISI 304-AISI 304, AISI 304Galvanis dan Galvanis-Galvanis. Hasil penelitian menunjukkan bahwa perbedaan material memberikan dampak terhadap kekuatan fatik dari hasil las yang seperti terlihat pada gambar 7. Gambar tersebut menunjukkan kekuatan fatik untuk diameter nugget yang sama pada sambungan plat baja AISI 304-AISI 304 dan Galvanis-Galvanis lebih tinggi dibandingkan sambungan plat baja Galvanis-Galvanis.

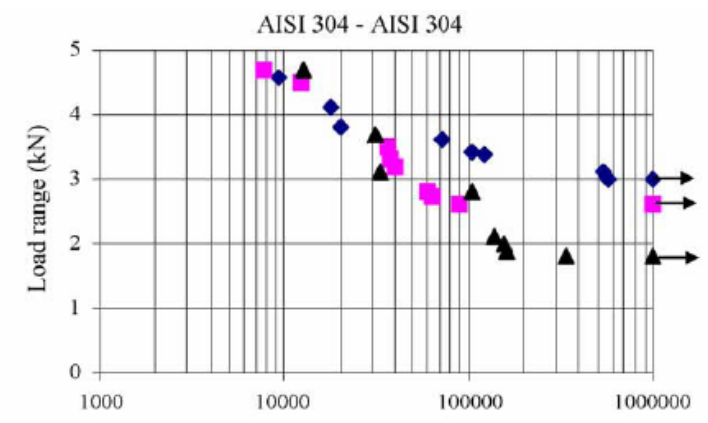

(a)

Number of cycles to failure

Nugget dia. $4 \mathrm{~mm}$. Nugget dia. $5 \mathrm{~mm}$. Nugget dia. $6 \mathrm{~mm}$.

(a)

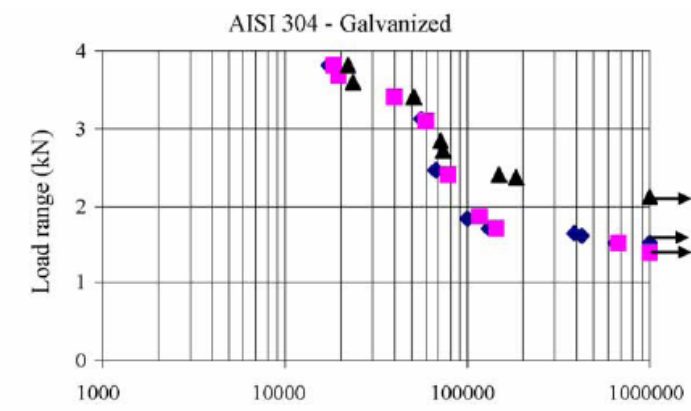

(b) Number of cycles to failure

- Nugget dia. $4 \mathrm{~mm}$. Nugget dia. $5 \mathrm{~mm}$. $\Delta$ Nugget dia. $6 \mathrm{~mm}$.

(b)

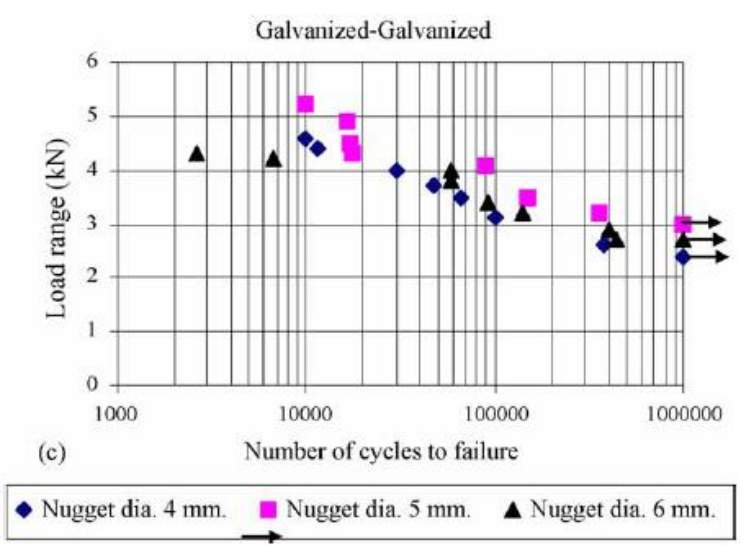

(c)

Gambar 7. Kurfa untuk pengelasan titik spesimen: (a) Susunan plat AISI 304-AISI 304; (b) Susunan plat GalvanisGalvanis; (c) Susunan plat Galvanis-Galvanis [5]. 
Perbedaan susunan material pada pengelasan titik juga berdampak terhadap hasil las. Hal ini pernah diteliti oleh Nielsen dkk [6] yang melakukan penelitian tentang pengaruh susunan plat, kuat arus listrik, diameter tip elektroda dan waktu pengelasan terhadap ukuran diameter nugget dan kekuatan geser (tensile shear strength) pada proses las titik. Material yang digunakan adalah plat tipe HSLA 340, DP 600, TRIP 700. Pada penelitian ini plat dilas menggunakan spot welding dengan susunan 3 lapis. Hasil penelitian menunjukkan diameter tip elektroda berpengaruh terhadap ukuran diameter nugget. Semakin besar ukuran tip elektroda yang digunakan untuk parameter yang sama menghasilkan diameter lebih besar. Meningkatnya ukuran diameter nugget hasil las berdampak meningkatnya sifat mekanik yaitu kekuatan geser seperti terlihat pada Gambar 8.

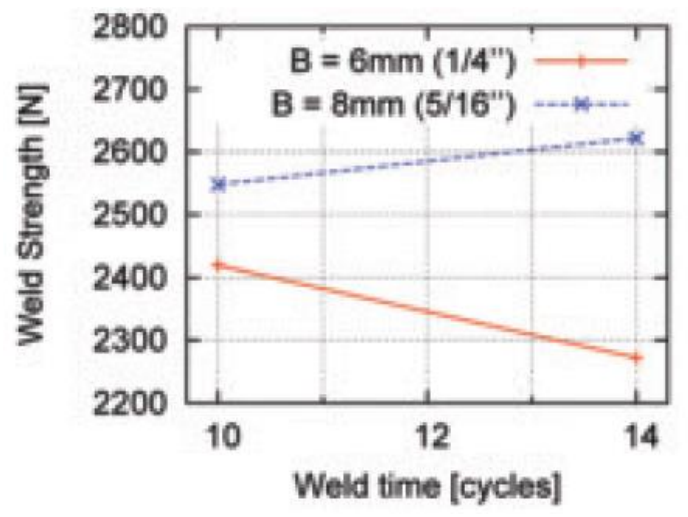

Gambar 8. Pengaruh beda diameter dan waktu pengelasan [6].

Pengelasan titik menyebabkan logam mengalami perubahan sifat mekanik salah satunya nilai kekuatan tekan. Logam mengalami perubahan struktur mikro untuk daerah FZ (Fusion Zone) dan HAZ (Heat Affected Zone) akibat panas yang ditimbulkan oleh aliran listrik. Penelitian pengaruh las titik terhadap kekuatan tekan telah dilakukan oleh Kong dkk [3] yang melakukan penelitian tentang kekuatan las spot welding pada baja karbon rendah secara numerical. Hasil penelitian menunjukkan kekerasan logam antara daerah FZ (Fusion Zone), HAZ (Heat Affected Zone) dan BM (BaseMetal) berbeda seperti terlihat pada gambar 9.

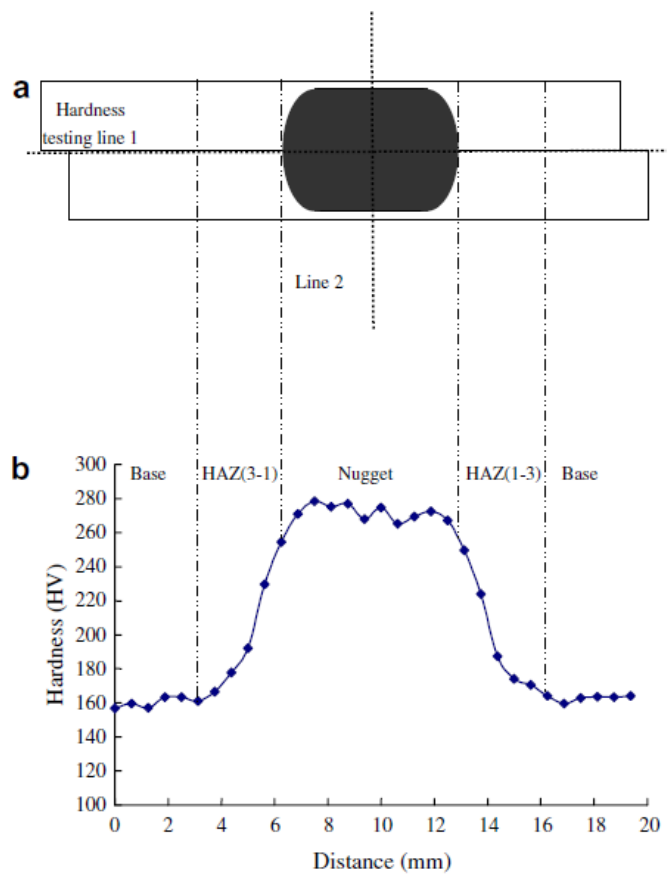

Gambar 9. Distribusi kekerasan pada plat gabungan. (a). Tes uji kekerasan mikro; (b). Distribusi kekerasan sepanjang permukaan plat [3].

Distribusi kekerasan logam pada daerah FZ (Fusion Zone) memiliki nilai hampir seragam. Semakin besar kuat arus berdampak meningkatnya diameter nugget. Akan tetapi meingkatnya diameter nugget tidak berpengaruh terhadap distribusi kekerasan logam. Penelitian tentang kekerasan logam hasil las titik telah oleh Shamsul dan Hisyam [7] yang 
melakukan penelitian tentang pengelasan titik (resistance spot welding) pada logam baja tahan karat tipe 304. Penelitian ini membahas pengaruh dari peningkatan arus listrik terhadap distribusi kekerasan seperti terlihat pada gambar 10 .

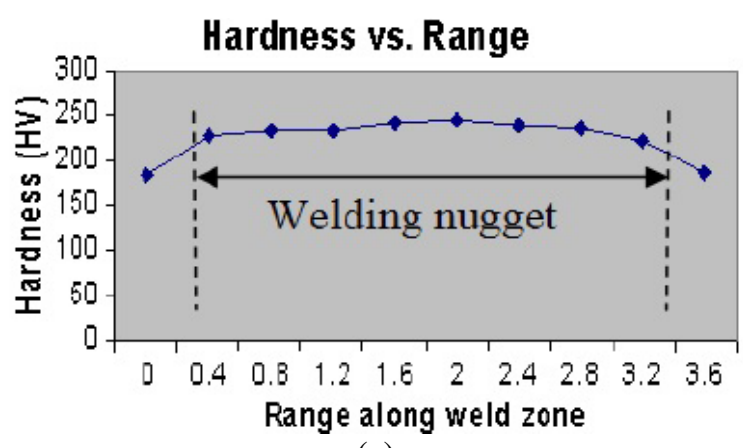

(a)

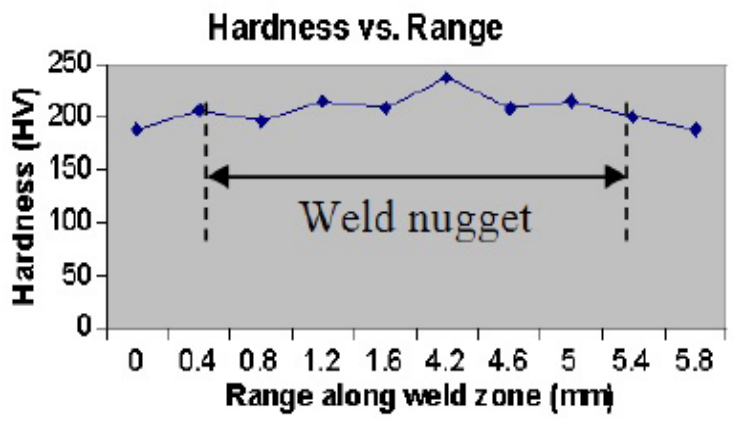

(b)

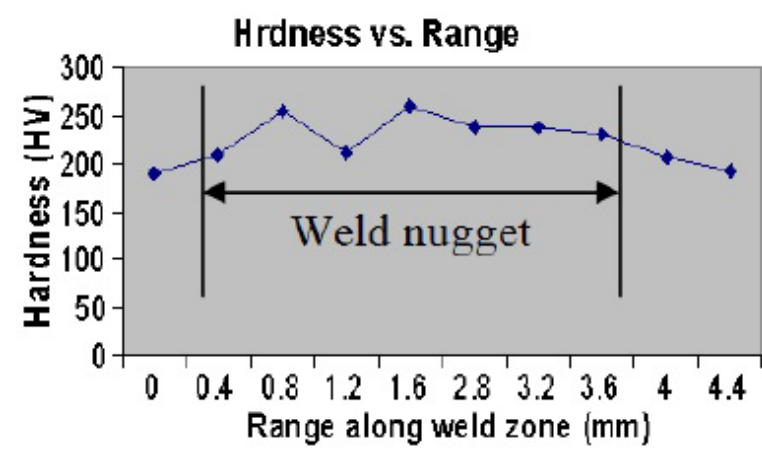

(c)

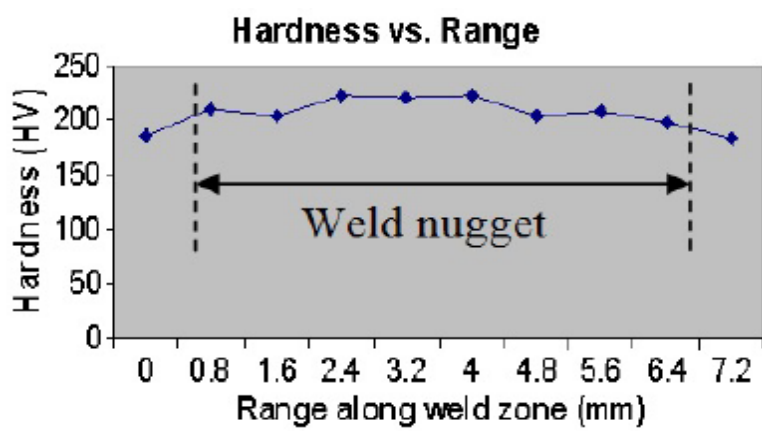

(d)

Gambar 10. Uji kekerasan pada las titik variasi arus: (a) $2.5 \mathrm{kA}$; (b) $3.75 \mathrm{kA}$; (c) 5 kA; (d) $6.25 \mathrm{kA}$ [7].

Penelitian tentang las titik dengan menggunakan logam yang sejenis yaitu baja karbon rendah terlapisi seng dan tanpa terlapisi telah dilakukan oleh N. Harlin dkk [8]. Hasil penelitian menunjukkan ukuran diameter nugget yang dihasilkan oleh baja karbon rendah terlapisi lebih kecil dibandingkan dengan baja karbon tanpa terlapisi pada waktu dan 
arus pengelasan yang sama ditunjukkan pada Gambar 11. Baja karbon rendah terlapisi seng memiliki hambatan listrik lebih rendah dibandingkan dengan baja karbon tanpa terlapisi. Oleh karena itu diperlukan arus listrik dan waktu pengelasan lebih tinggi untuk memiliki diameter nugget yang sama dengan baja karbon tanpa terlapisi.

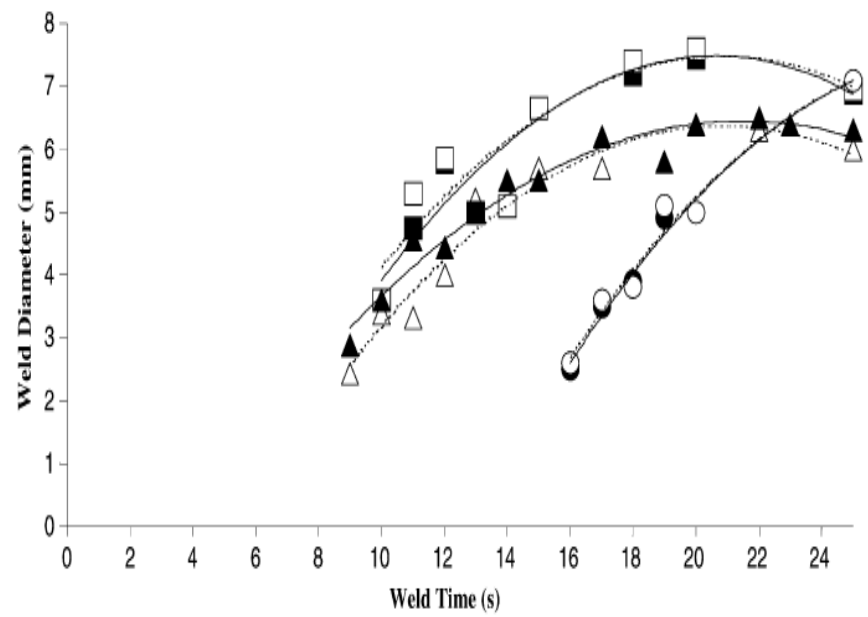

Gambar 11. Pengaruh ukuran diameter nugget terhadap waktu pengelasan dengan variasi gaya elektroda (EF); atas dan $(\triangle)$ bawah tidak terlapisi seng pada EF 2,1 kN; $\square$ ) atas dan $(\boldsymbol{\square})$ bawah terlapisi seng pada EF 2,1 kN; dan bawah ( ) terlapisi seng pada $6,0 \mathrm{kN}[8]$.

Kemampuan las titik untuk berbagai material adalah saling berbeda antara material satu dengan material lainnya. Penelitian tentang pengelasan titik menggunakan logam tak sejenis telah dilakukan oleh Hayat [9]. Bahan yang digunakan adalah baja BH180, IF7123, AISI304L dengan dimensi 100x30 mm. Arus listrik dalam pengelasan dibuat seragam yaitu $9 \mathrm{kA}$. Hasil penelitian menunjukkan bahwa sambungan las antara BH-IF memiliki heat input jauh lebih besar dibandingkan BH-SS. Baja BH180 dan IF7123 memiliki nilai konduktivitas listrik (J) sebesar 0,0000142 $\Omega / \mathrm{cm}$ dan untuk baja AISI304L sebesar $0,0000720 \Omega / \mathrm{cm}$. Besar nilai konduktivitas listrik akan berdampak terhadap besar heat input seperti ditunjukkan pada gambar 12. Hasil uji kekerasan menunjukkan sambungan las antara baja BH-SS lebih tinggi dibandingkan baja BH-IF seperti terlihat pada gambar 13. Nilai kekuatan beban daya dukung (tensile load bearing capasity) hasil uji kekuatan geser pada sambungan las antara baja BH-SS juga lebih tinggi seperti terlihat pada Gambar 14.

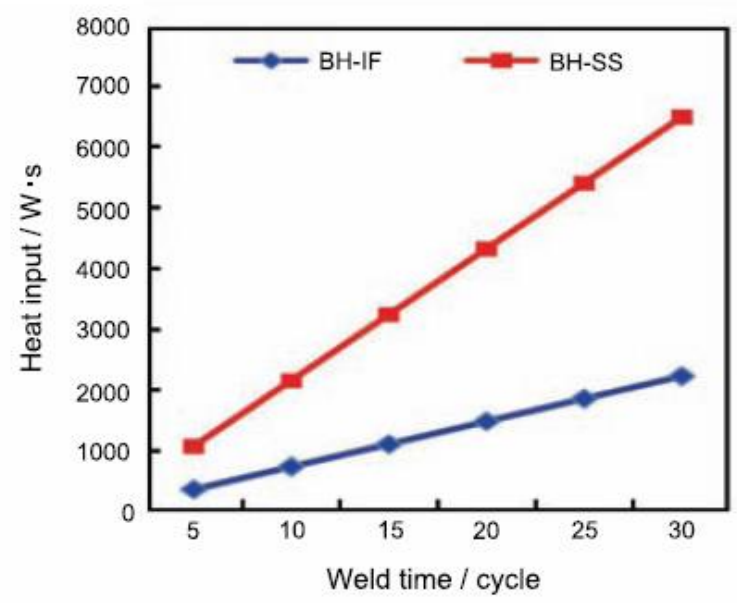

Gambar 12. Variasi heat input dengan waktu pengelasan [9]. 


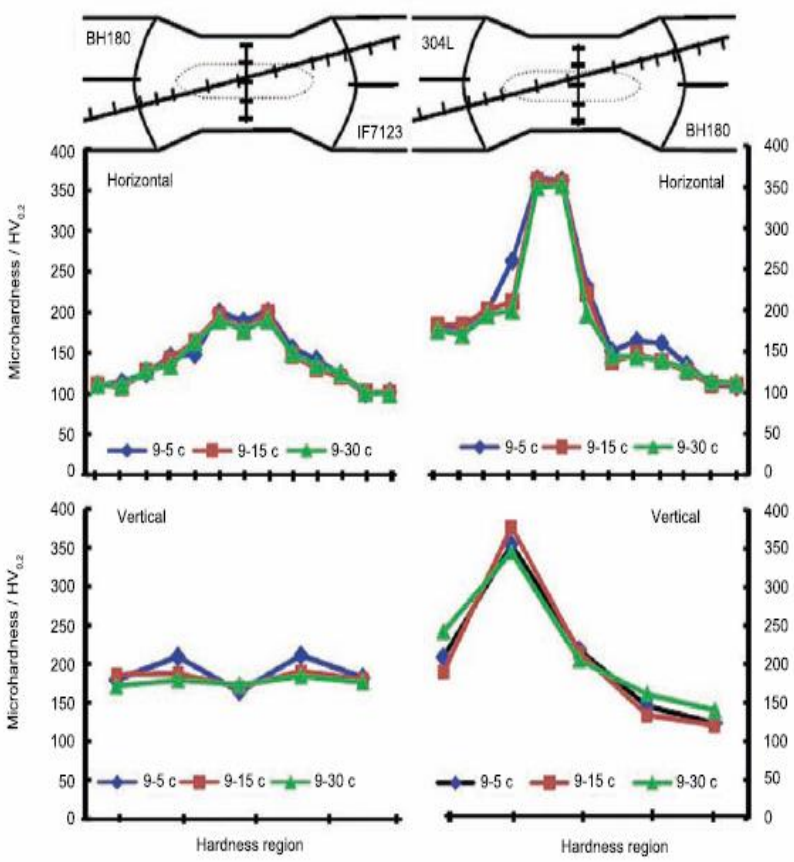

Gambar 13. Profil kekerasan dari spesimen [9].

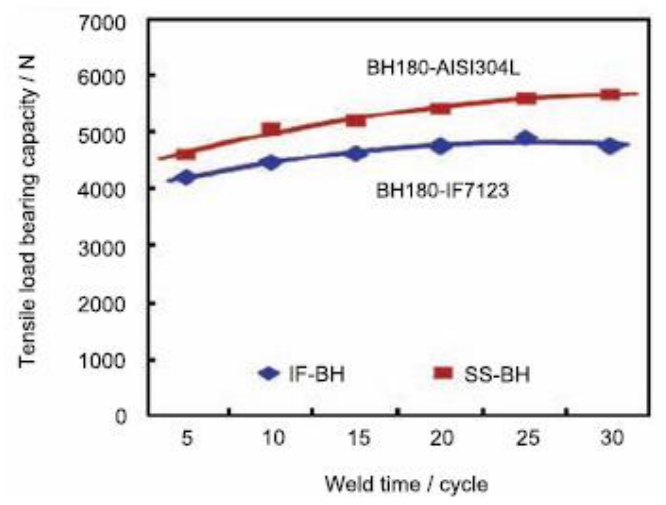

Gambar 14. Pengaruh waktu pengelasan terhadap beban daya dukung pada sambungan las [9].

Penelitian tentang sambungan las antara baja karbon rendah dengan baja tahan karat telah dilakukan oleh Ladislav dkk [10]. Spesimen yang digunakan baja karbon rendah DC01(LCS) dan AISI 304 (ASS). Hambatan listrik logam ASS memiliki nilai sebesar $72 \mu \Omega . \mathrm{cm}$, sedangkan logam LCS sebesar $14.2 \mu \Omega . \mathrm{cm}$. Hasil uji strukturmakro menunjukkan ketidaksimetrisan dari nugget hasil las seperti terlihat pada Gambar 15.

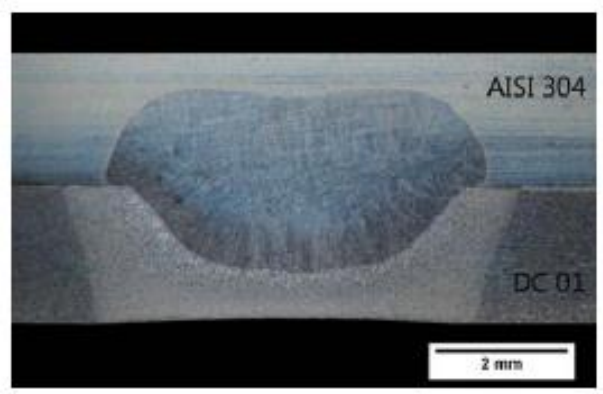

Gambar 15. Makrostruktur spesimen las titik [10].

Penelitian tentang las titik menggunakan logam tak sejenis juga pernah dilakukan oleh Ahmet Hasanbasoglu dan Ramazan Kacar [11]. Penelitian dilakukan untuk menggabungkan baja AISI 316 L dan baja DIN EN 10130-99 dengan memvariasikan kuat arus listrik. Hasil penelitian menunjukkan nugget yang dihasilkan pada baja DIN EN 10130-99 (IF7114) lebih besar dibandingkan dengan baja DIN EN 10130-99 seperti terlihat pada Gambar 16. 
Parameter waktu pengelasan juga sangat berpengaruh terhadap kekuatan geser nugget las. Penelitian tentang las titik menggunakan logam sejenis dilakukan oleh Anlanlar [12] menggunakan material baja paduan galvanis dengan ukuran $23 \mu \mathrm{m}$. Hasil penelitian menunjukkan waktu pengelasan berdampak terhadap ukuran diameter nugget. Waktu pengelasan meningkat maka diameter nugget semakin meningkat. Hal ini berdampak terhadap meningkatnya kekuatan geser hasil sambungan las titik seperti yang ditunjukkan pada gambar 17. Waktu pengelasan merupakan waktu antara awal penerapan gaya elektroda pada spesimen sampai tahap pelepasan. Semakin lama waktu pengelasan yang digunakan memungkinkan nugget hasil las mengalami pendinginan lebih lama. Dengan demikian nugget hasil las semakin kuat.
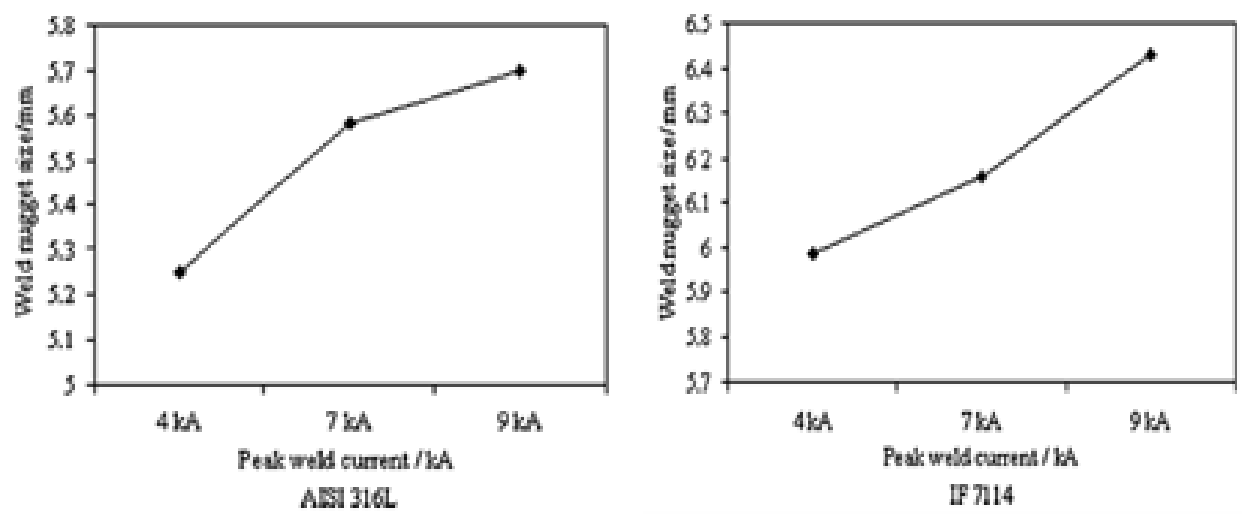

Gambar 16. Hubungan antara ukuran nugget dan kuat arus [11].

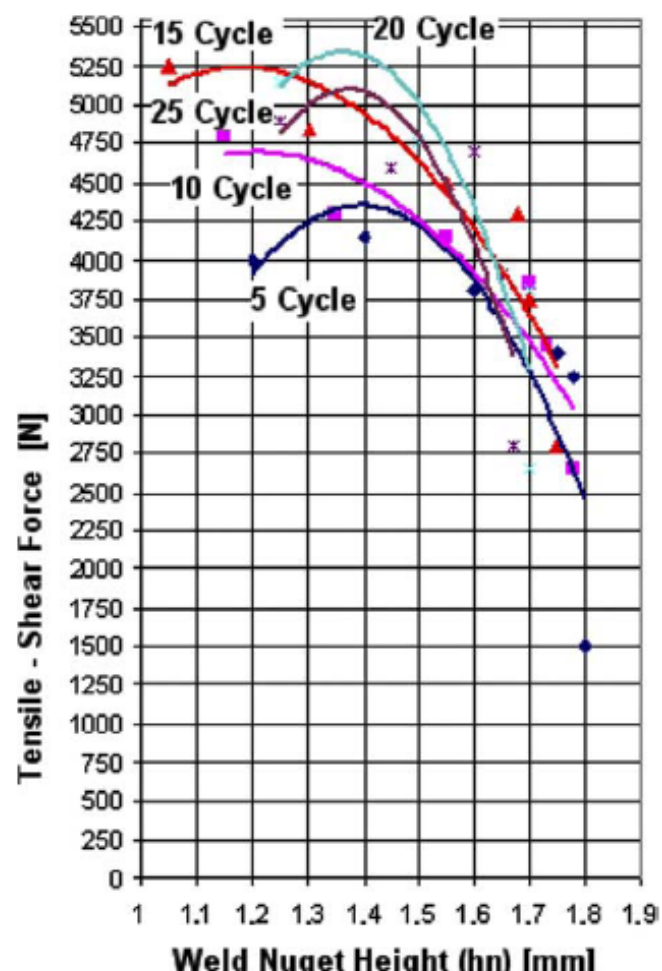

Gambar 17. Hubungan antara ukuran nugget dan kekuatan geser [12].

\section{PEMBAHASAN}

Heat input yang dihasilkan pada proses pengelasan titik sangat berpengaruh terhadap kelayakan hasil sambungan las. Permasalahan yang sering terjadi adalah ketika melakukan pengelasan untuk menyambungkan 2 logam atau lebih yang memiliki ketebalan berbeda pada material sejenis, material tak sejenis dengan ketebalan sama, atau kombinasi dari keduanya. Hasil uji strukturmikro untuk sambungan las titik logam sejenis dapat dilihat pada daerah fusi memiliki bentuk nugget yang simetris. Hal ini dikarenakan logam sejenis memiliki propertis sifat fisik dan mekanik yang sama sehingga panas yang muncul pada daerah antar sisi logam seragam. Heat input yang seimbang berdampak pada penetrasi tiap logam sama. Bentuk nugget hasil las yang simetris berdampak terhadap sifat mekanik sambungan las 
yaitu kekuatan gesernya. Pengelasan untuk logam tak sejenis memiliki bentuk nugget yang tidak simetris akibat perbedaan sifat fisik dan mekanik antar logam satu dengan lainnya. Bentuk nugget yang tidak simetris akan berdampak menurunnya kekuatan geser sambungan las. Parameter yang sama dalam pengelasan untuk sambungan las logam sejenis akan menghasilkan kekuatan geser lebih besar dibandingkan logam tak sejenis. Sifat mekanik yang lain yaitu kekuatan fatik juga berpengaruh pada sambungan las titik antara logam sejenis dengan logam tak sejenis. Logam sejenis memiliki kekuatan fatik lebih besar dibandingkan dengan logam tak sejenis. Panas yang dihasilkan dalam pengelasan titik berdampak terhadap perubahan fasa pada logam. Pada sambungan las logam sejenis, dari hasil pengujian strukturmikro dapat dilihat bahwa terjadi perubahan fasa pada daerah HAZ dan fusi. Sedangkan hasil pengujian strukturmikro pada sambungan logam tak sejenis memiliki perbedaan fasa antar logam satu dengan lainnya. Hal ini dikarenakan logam satu dengan lainnya memiliki fasa yang berbeda. Perubahan fasa ini akan berdampak pada nilai kekerasan suatu logam. Hasil penelitian terdahulu menunjukkan logam sejenis dan tak sejenis untuk daerah fusi memiliki kekerasan jauh lebih tinggi dibandingkan daerah HAZ maupun logam induk.

\section{KESIMPULAN}

Kesimpulan yang bisa diperoleh dari pembahasan di atas adalah Pengelasan logam sejenis dengan ketebalan yang sama menghasilkan bentuk nugget yang simetris. Sedangkan pengelasan logam tak sejenis dengan ketebalan berbeda menghasilkan bentuk nugget tidak simetris (asimetris). Parameter pengelasan seperti arus listrik, lama waktu pengelasan dan acuan standar pengujian untuk logam sejenis tidak bisa digunakan pada pengelasan logam tak sejenis. Acuan yang digunakan dalam pengelasan logam tak sejenis adalah ukuran diameter nugget. Semakin besar ukuran diameter nugget hasil las semakin meningkat kekuatan gesernya.

\section{REFERENSI}

[1] Pouranvari, M., 2011, "Effect of Welding Current on the Mechanical Response of Resistance Spot Welds of Unequal Thickhness Steel Sheets in Tensile-Shear Loading Condition: International Journal of Multidisciplinary Science and Engineering," Vol. 2, No. 6.

[2] Ninshu, M., and Murakawa Hidekazu., 2009. "Numerical and Experiment Study on Nugget Formation in Resistance Spot Welding for High Strength Steel Sheets in Automobile Bodies: Transactions of JWRI," Vol. 38, No. 2.

[3] Kong, X., Q. Yang., B. Li., G. Rothwell., R. English., and X.J. Ren., 2008. " Numerical Study of Strength of Spotwelded Joints of Steel: Journal of Materials and Design," 29: 1554-1561.

[4] Dongho, B., Taehun, N., and Wonseok, J., Welded Multi-Lap Joint By The Maximum Stress Intensity Factor, Kөmax: International Journal of Modern Physics B," Vol. 17, No. $8 \quad$ \& 9: 1646-1652.

[5] Vural, M., A. Akkus, B. Eryurek., 2006. "Effect of Welding Nugget Diameter on the Fatigue Strength of the Resistance Spot Welded Joints of Different Steel Sheets: Journal of Materials Processing Technology," 176: 127-132.

[6] Nielsen, C.V., K. S. Friis, W. Zhang, and N. Bay., 2011. "Three-Sheet Spot Welding of Advanced High-Strength Steels: Welding Research," Vol. 90.

[7] Shamsul, J.B., and M. M. Hisyam., 2007. "Study of Spot Welding of Austenitic Stainlees Steel Type 304: Journal of Applied Sciences Research," 3 (11): 1494-1499.

[8] Harlin, N., T.B. Jones, and J.d. Parker., 2003. "Weld Growth Mechanism of Resistance Spot Welds In Zinc Coated Steel: Journal of Materials Processing Technology," 143-144: 448-453.

[9] Fatih, H., 2011. "Resistance Spot Weldability of Disimilar Matrials: BH180-AISI304L Steels and BH180-IF7123 Steel: J. Master. Sci. Technol," 27: 1047-1058.

[10] Kolarik, L., Miroslav Sahul, Marie Kolarivoka, Martin Sahul, Milan Turna, and Michal Felix., 2012. " Resistance Spot Welding of Dissimilar Steels: Acta Polytechnica," Vol. 52, No. 3.

[11] Hasanbasoglu, A., Ramazan Kacar., 2007. "Resistance Spot Weldability of Disimilar Materials (AISI 316 L-DIN EN 10130-99 Steels): Material and Design," 28: 1794-1800.

[12] Aslanlar, S., 2004. "The Effect of Nucleus Size on Mechanical Properties in Electrical Resistance Spot Welding of Sheets Used in Automotive Industry: Material and Design. 